DOI: $10.15290 /$ bsl.2018.12.11

\author{
Maria Makaruk \\ Wydział Polonistyki \\ Uniwersytet Warszawski \\ e-mail: maria.makaruk@uw.edu.pl \\ ORCID: 0000-0002-9210-5533
}

\title{
Nad trumną bohatera romantycznego
}

Kordian $\mathrm{w}$ reżyserii Jakuba Skrzywanka stanowi jeden z najciekawszych teatralnych głosów w sprawie dramatu Słowackiego od kilkunastu, a może nawet kilkudziesięciu lat ${ }^{1}$. Choć spektakl wpisany jest $\mathrm{w}$ ramę naśladującą budowę Kordiana, a kwestie spoza tekstu dramatu powracają w etiudach, które stanowią ekwiwalenty jego brakujących fragmentów - trudno nazwać go inscenizacją. Deklarując, że zamierza Kordiana pochować, reżyser zasygnalizował bowiem między słowami projekt zmierzenia się z tradycją czytania i grania Kordiana, która pokutuje w polskim teatrze od dnia krakowskiej prapremiery ${ }^{2}$.

W jednym z wywiadów Skrzywanek powiedział, że przed przystąpieniem do pracy nad Kordianem „miał nieszczęście zobaczyć dwa niedobre wystawienia dramatu Słowackiego - w Teatrze Narodowym w Warszawie i w teatrze we Wrocławiu" ${ }^{3}$ i że "czas, żeby o Kordianie opowiedzieli jego

\footnotetext{
1 Kordian, reż. J. Skrzywanek, Teatr Polski w Poznaniu, premiera 12 stycznia 2018 roku.

2 Prapremiera Kordiana odbyła się 25 listopada 1899 roku w Teatrze Miejskim w Krakowie w reżyserii Tadeusza Kotarbińskiego. Zdaniem badacza dziejów scenicznych dramatu romantycznego, Michała Masłowskiego, Kordian stawał się „symbolem tragizmu losu Polaków walczących o wolność", zaś przedstawienie, zdaniem części krytyków, reprezentowało "styl popularno-patriotyczny". Por. M. Masłowski, Dzieje bohatera. Teatralne wizje "Dziadów”, "Kordiana” i "Nie-Boskiej Komedii" do II wojny światowej, Wrocław 1978, s. 92-93.

3 Kordian, reż. J. Englert, Teatr Narodowy w Warszawie, premiera 19 listopada 2015 roku; Kordian czyli panoptikum strachów polskich, reż. A. Sroka, Teatr Polski we Wrocławiu, premiera 12 maja 2017 roku.
} 
równolatkowie" ${ }^{4}$. Dwa przedstawienia, na które wskazał reżyser, niezależnie od krzywdzącego zrównania ich wartości artystycznej, istotnie realizują pod pewnym względem wspólny scenariusz - oba bazują na pewnej tradycji lektury i gry dramatu Słowackiego, wpisując się w ten sposób bardziej w dzieje recepcji niż rzeczywistej interpretacji Kordiana. W "rocznicowej” inscenizacji dramatu Słowackiego Englert stworzył erudycyjny kolaż romantycznych tekstów i odwołań do klasyków sceny narodowej: Axera, Dejmka, Hanuszkiewicza, Jarockiego i Grzegorzewskiego. Kordianów jest tu trzech (dwóch młodych, jeden dojrzały), partnerują im dwie Laury i pięć Wiolett. Mimo wpisania dramatu Słowackiego w podwójny nawias - ramy kabaretowego Variété i Goetheańskiego Fausta - Englert traktuje paradygmat romantyczny poważnie, język ironii wykorzystując wyłącznie jako etap na drodze do Wielkiego Serio. Dowodzi tego dobitnie patetyczna scena finałowa, w której Kordiana otaczają na scenie inni "chłopcy polscy", trzymający się za przebite kulami serca. Adam Sroka zadeklarował z kolei stworzenie opowieści o „buntowniku, zapaleńcu i marzycielu" (także występującym w młodej i dojrzałej postaci), wpisując jego „wędrówkę przez różne kręgi swojego "piekła « w konwencję tytułowego "panoptikum strachów polskich «" ${ }^{5}$. Wrocławski spektakl, stanowiący zlepek chronologicznie następujących po sobie scen i pozbawiony autorskiej interpretacji, grzeszy dosłownością, brakiem jakiejkolwiek refleksji nad sensem wypowiadanych zdań, patosem i dydaktyzmem - w finale, na stanowiącym laitmotiv walcu cis-moll Chopina, wybrzmiewają gorzko słowa Kordiana: „tak wam płacono”, osadzające lekturę dramatu Słowackiego w nurcie patriotyczno-rozliczeniowym.

Mimowolnie tłem dla spektaklu Skrzywanka staje się także kielecka inscenizacja Kordiana z maja 2015 roku, wyreżyserowana przez Piotra Szczerskiego $^{6}$. Nieukrywający swoich sympatii politycznych reżyser zaplanował premierę na weekend poprzedzający wybory prezydenckie, tak rozkładając akcenty między dobrem a złem, żeby móc cały ówczesny obóz rządzący usytuować po stronie piekielnej, nadając przy tym carowi oblicze Władimira Putina. Szczerski, potraktowawszy Kordiana jako figurę polskiego losu, wcielenie bohatera, który, wciągnięty w wiry wielkiej historii, zostaje przez nią unicestwiony, buduje patetyczną opowieść o honorze i konieczności po-

\footnotetext{
4 V. Szostak, Jakub Skrzywanek: Chcę pochować Kordiana. Teatr Polski wystawia dzieło Słowackiego. Punkowa Siksa w roli Kordianki, „Gazeta Wyborcza: Magazyn Poznański”, 12.01.2018, http:// poznan.wyborcza.pl/poznan/7,105531,22883342,jakub-skrzywanek-chce-pochowac-kordianateatr-polski-wystawia.html?disableRedirects=true [dostęp 4.11.2018].

5 http://www.teatrpolski.wroc.pl/przedstawienie/kordian-czyli-panoptikum-strachowpolskich/ [dostęp 16.01.2019].

6 Kordian, reż. P. Szczerski, Teatr im. S. Żeromskiego w Kielcach, premiera 3 maja 2015.
} 
święcenia się w imię zasad, wplatając w tkankę spektaklu wątek katyński. Kordian to u Szczerskiego szlachetny buntownik, który przegrywa - bo taki jest odwieczny los Polaków, zawsze stających po stronie prawdy i przeciwstawiających się złu.

Mimo skrajnej odmienności koncepcji, reżyserzy wszystkich trzech inscenizacji wykorzystali dramat Słowackiego jako tekst stanowiący matrycę do opowiadania o "polskim losie”. Konsekwencją przyjęcia takiej strategii było jednak potraktowanie Kordiana jako drugiego po Dziadach dramatu narodowego, odmiennego $\mathrm{w}$ pewnych konkretnych diagnozach (czyn zamiast biernego cierpienia), ale pełniącego $\mathrm{w}$ gruncie rzeczy podobne, mitotwórcze funkcje. Żeby jednak oddać sprawiedliwość Englertowi, Szczerskiemu i Sroce, warto przypomnieć, że Kordian sprawiał kłopoty czytelnikom już od momentu publikacji ${ }^{7}$. Słowacki bowiem tylko na pozór szedł krok w krok za Mickiewiczem, w rzeczywistości niemalże na każdym poziomie wchodząc z nim w polemikę. Poczynając od motta, odsyłającego do nihilistycznego poematu o korsarzu - morfiniście, pokutującym za to, że „nie skonał, gdy inni konali”, przez Przygotowanie, z którego można wywnioskować, że historia Polski stała się igraszką szatanów, a wszelkie próby działania można raczej przyrównać do teatrzyku marionetek, po Prolog, wprost ujawniający teatralny potencjał dramatu, Kordian jest tekstem skrajnie od Dziadów odmiennym. Do takiej refleksji powinien był skłaniać pierwszych czytelników sam wybór imienia bohatera, które jednocześnie stało się tytułem całej „trylogii dramatycznej”. Kordian to bowiem nie tyle „inny" Konrad ani „człowiek serca”, ile „człowiek chory na serce" 8 - bohater, który klęskę ma wpisaną w biografię.

Najciekawsze współczesne (i nowoczesne) lektury Kordiana koncentrują się wokół wątków egzystencjalnych, problematyki nihilizmu i ironii ${ }^{9}$. Dramat Słowackiego jest także utworem ostentacyjnie eksponującym swoją teatral-

7 Por. Wspótcześni o „Kordianie”, w: M. Bizan, P. Hertz, Glosy do „Kordiana”, Warszawa 1972, s. $126-142$.

8 „Wyrazy z rdzeniem kor- oznaczają w każdym prawie przypadku zarówno pewne stany fizyczne (chorobę), jak i dyspozycje uczuciowe. Oto materiał z Lindego: kordiaczny - 1. Cierpiący kordiakę, cardicus; 2 . Swarliwy, śmiały, czupurny, sierdzisty; [...] kordiaka - niemoc, »kiedy człowiek cierpi wielkie uciążenie na sercu i inszych wnętrznościach pod piersiami «, »serca tkliwość«", Por. M. Bizan, P. Hertz, Glosy do „Kordiana”, s. 199.

9 Por. np. M. Kuziak, Stowacki - nihilistyczny? Wokót "Kordiana”, w: Nihilizm i historia. Studia z literatury XIX i XX wieku, red. M. Sokołowski, J. Ławski, Białystok 2009; M. Piwińska, Złe wychowanie, Gdańsk 2005, s. 89-132; W. Szydłowska-Brykczyńska, Egzystencjalistyczne królestwo albo romantyzm na wygnaniu, Chotomów 1991, s. 49-75; R. Fieguth, Granice ironii w "Kordianie" Juliusza Słowackiego, w: Ciało, płeć, literatura. Prace ofiarowane prof. Germanowi Ritzowi, w pięćdziesiątą rocznicę urodzin, red. M. Hornung, M. Jędrzejczak, Warszawa 2001; M. Siwiec, Stowacki i nowoczesność, w: Romantyzm i nowoczesność, red. M. Kuziak, Kraków 2009, zwł. s. 117-138 i in. 
ność i polifonicznym ${ }^{10}$ - nie dziwi zatem, że przez prawie sto dwadzieścia lat obecności w teatrze stawiał opór inscenizatorom. Prześledzenie dziejów scenicznych dramatu dowodzi bowiem, że najgłośniejsze i najlepiej zapamiętane inscenizacje uruchamiały na scenie wątki narodowe (Kordian jako figura patriotyzmu i antykonformizmu), podczas gdy spektakle dotyczące kwestii egzystencjalnych lub zbudowane na figurze ironii można policzyć na palcach jednej ręki ${ }^{11}$. Bodajże tylko Jerzy Grotowski w 1962 roku poddał krytycznej refleksji sens kordianizmu i mitów ofiarniczych, nikt (albo prawie nikt) nie traktował ramy delimitacyjnej Kordiana jako narzędzia dystansującego wobec iluzji dramatycznej. Warto zaś pamiętać, że Słowacki to nie tylko, jak powiada Dariusz Kosiński, jeden z pięciu największych dramatopisarzy świata ${ }^{12}$, lecz także mistrz ironii romantycznej.

Choć ironia (także romantyczna) jest w poznańskim Kordianie głównym narzędziem budowania porozumienia między twórcami a widownią, Jakub Skrzywanek do zadania realizacji Kordiana podszedł bardzo poważnie, co można wyczytać nie tylko ze składanych przez niego deklaracji, lecz także $\mathrm{z}$ opowieści zaangażowanych $\mathrm{w}$ projekt aktorów. Role $\mathrm{w}$ tym spektaklu nie zostały bowiem „rozdane” - aktorzy wspólnie zdecydowali, kogo chcą zagrać i dlaczego. W rezultacie na scenie pojawia się jedna Kordianka (Alex Freiheit), pięciu Kordianów (Konrad Cichoń, Paweł Siwiak, Kornelia Trawkowska, Magdalena Woleńska, Wiesław Zanowicz) i jeden Nie-Kordian (Mariusz Adamski). Tylko Sonia Roszczuk zdecydowała się na wybór postaci Winkelrieda. Bohater sceniczny stał się więc konstrukcją polifoniczną, powstałą ze skrzyżowania rozmaitych perspektyw, w czym można upatrywać gestu dochowania wierności autorskiej strategii Juliusza Słowackiego. Dariusz Kosiński słusznie zauważa:

Imiona te nie są nazwami postaci czy ról, lecz określają stosunek aktorów do postaw, sposobów istnienia w świecie czy tematów, których wiązki tworzą dynamiczną całość opisywaną jako Kordian. Już zatem w samym punkcie wyjścia twórcy przedstawienia rezygnują z poszukiwania tak kiedyś (a i dziś przez niektórych) wysoko cenionej spójności i jednolitości postaci. Można w tej wielogłosowości Kordiana, rozpisanego na cały niemal zespół, widzieć jakąś strategię współczesnego teatru, ale w rzeczywistości jest to zabieg stuprocentowo zgodny z tekstem Słowackiego, w którym tożsamość Kordiana jest radykalnie niepewna.

10 Por. np. J. Maciejewski, Kordian. Dramatyczna trylogia, Poznań 1961; M. Chacko, Dramat i teatr Juliusza Stowackiego. Rekonesans, Wrocław 2006; A. Kurska, Fragment i całość w dramaturgii Juliusza Słowackiego, w: Słowacki teatralny, red. K. Kurek, Poznań 2006, s. 85-105 i in.

11 Por. M. Masłowski, Dzieje bohatera..., s. 182-195; L. Kaczyńska, Winkelried ożyt. Teatralne odczytywanie „Kordiana” (1945-2000), Gdańsk 2006, zwł. s. 69-118, 132-154, 167-182.

12 D. Kosiński, Doprawdy, nie wiem, co mu jest, „Tygodnik Powszechny” 2018, nr 7, s. 68. 
To bohater hiperdynamiczny, poszukujący sam siebie właśnie dlatego, że nie wybrał swojej społecznej roli, swojej persony. Więcej nawet: żadna z ról, jakie podsuwa mu świat, nie satysfakcjonuje go, nie daje spełnienia ${ }^{13}$.

Grę z budową i strukturą Kordiana Jakub Skrzywanek, dramaturżka Daria Kubisiak i scenografka Paula Grocholska, podejmują już od pierwszych chwil. W poznański spektakl wchodzi się bowiem stopniowo. Jeszcze przed wejściem do budynku teatru wzrok widzów przykuwa stojąca na podwyższeniu, skąpana w blasku halogenów sosnowa trumna. Na trumnie - polska flaga, wiązanka biało-czerwonych róż i tabliczka z inskrypcją: „Wy jesteście krainy sumnienie, Zburzcie się i z dusz waszych odrzućcie grzech cara". Z głośnika w foyer płynie komunikat, zachęcający do bliższego przyjrzenia się „przestrzeni instalacji performatywnej”, w której będzie się toczył spektakl. Nad sceną Malarni - jeśli uwierzyć megafonom - „wiernie oddającej założenia Placu Adama Mickiewicza w Poznaniu" góruje makieta poznańskich Krzyży. Pozostałe rekwizyty są jednak bardzo umowne - to podesty oznaczone tabliczkami informacyjnymi, odsyłające zarówno do historii Poznania, jak i postaci wieszczów (Mickiewicz i Słowacki), artystów-patriotów (Ignacy Jan Paderewski), świętych polskich (Jan Paweł II) i polityków, spotykających się przy Pomniku Krzyży. Nie zabrakło masztów i zniczy, zaś miejsce na jednym $\mathrm{z}$ postumentów zajmuje ubrany $\mathrm{w}$ dziewiętnastowieczny mundur Wiesław Zanowicz - aktor Teatru Polskiego w Poznaniu, a zarazem odtwórca roli Kordiana z 1979 roku w Rzeszowie. Stojący w rogu fortepian, przy którym w spektaklu zasiądzie jeden z Kordianów, odgrywa jednocześnie rolę „fortepianu Paderewskiego”. Wyposażeni w plan instalacji, w którym dominuje narracja ironiczna, widzowie mogą zatem skonfrontować z sobą różne dyskursy i doświadczyć ich wzajemnego obnażania się. Tematem instalacji nie jest bowiem przestrzeń Poznania, która pozwoliłaby na interpretowanie Kordiana w duchu Wyspiańskiego („tu i teraz”), ale przestrzeń egzystencji „wspólnoty wyobrażonej” - wypełniona nakładającymi się palimpsestowo kliszami, odsyłającymi wprost do paradygmatu romantycznego i wchodzącymi z nim w spór ${ }^{14}$.

\footnotetext{
13 Tamże, s. 69.

14 Dla przykładu w „Planie przestrzeni” punkt 1, czyli „Poznańskie Krzyże”, jest opisany w następujący sposób: „pomnik odsłonięty 28 czerwca 1981 r. 25 lat po wydarzeniach czerwca '56. Daty umieszczone na krzyżach upamiętniają ważne wydarzenia z historii Polski: 1956 - My strzelamy do nas - 49 zabitych i co najmniej 239 rannych. 1968 - My wyrzucamy nas z kraju - jest nas mniej o około 15-20 tys. 1970 - My strzelamy do nas - ok. 50 zabitych i ok. 1165 rannych. 1976 - My próbujemy się dogadać z nami. Nikt nie ginie. 1980 - w następstwie dłuższych kłótni dogadujemy się między sobą na chwilę. 1981 - Wypowiadamy sobie wojnę, w której my zabijamy 40 naszych".
} 
W oczekiwaniu na rozpoczęcie spektaklu widzowie mogą wysłuchać nagrań głosów twórczyń i twórców poznańskiego Kordiana. Formułowane na wiele sposobów pytania o znaczenie figury bohatera romantycznego i sensy mierzenia się z rolą Kordiana zapowiadają to, co za chwilę wydarzy się na scenie - i wraz z kolejną sekwencją stanowią ekwiwalent Przygotowania. Tak rekonstruuje tę scenę Dariusz Kosiński:

Po długim oczekiwaniu na początek spektaklu, w przestrzeń sceniczną [...] wychodzą wszyscy aktorzy we współczesnych strojach. Konrad Cichoń (jeden z Kordianów) zapowiada, że spektakl inicjuje obchody roku stulecia odzyskania niepodległości, a przed jego początkiem odczytany zostanie list od prezydenta RP Andrzeja Dudy. Jest to pismo pełne typowych zdań o wielkości narodu, wyrazów czci dla jego bohaterów i nawoływań do wzmożenia poczucia dumy, które zastąpić powinno pedagogikę wstydu. Z listu wynika, że jego autor (wątpię, by był nim prezydent) dawno nie czytał Kordiana, a z lekcji w liceum zapamiętał tyle, co większość Polaków - że to sztuka o bohaterach, walce i niepodległości. Jednak paradoksalnie ten list właśnie stanowi znakomite wprowadzenie do spektaklu, w którym pytania o niepodległość, naród i wielkość są traktowane zaskakująco poważnie ${ }^{15}$.

W liście prezydenckim szczególnie godny uwagi wydaje się fragment, z którego twórcy przedstawienia wyciągną wkrótce dalekosiężne konsekwencje. Wymieniwszy nazwiska „naszych narodowych bohaterów, ojców założycieli polskiej niepodległości” - Józefa Piłsudskiego, Romana Dmowskiego, Ignacego Jana Paderewskiego, Ignacego Daszyńskiego, Wincentego Witosa i Wojciecha Korfantego - autor puentuje swoją wypowiedź zdaniem: „To w nich widzimy Kordianów, jakich wymarzył sobie Słowacki”. Właśnie bowiem na figurze niezrozumienia i całkowitego przeinaczenia sensów dramatu Słowackiego będzie oparty spektakl Skrzywanka. Etiudę, skonstruowaną wokół obecnej w Przygotowaniu figury "mówców plemienia”, kończy wezwanie do uczczenia „bohaterów i męczenników, którzy oddali życie za wolność", minutą ciszy. Od tej chwili na oczach widzów będzie toczyła się polemika z wyobrażonymi sensami Kordiana - rodem z lektury szkolnej i prezydenckiego listu. Ironiczny nawias będzie jednak raz po raz uchylany, wchodząc w zmagania $\mathrm{z}$ formą dramatu Słowackiego.

Sceniczny ekwiwalent Prologu, stanowiącego rodzaj teatralnego credo Słowackiego, zostaje brawurowo odtańczony przez aktorów do dźwięków Mozartowskiego Dies Irae. Szalony taniec, budowany od minimalistycznych gestów: drgnięć, pojedynczych ruchów, potem sekwencji, jest jakby manifestem

15 D. Kosiński, Doprawdy, nie wiem, co mu jest, s. 69-70. 
wyzwolenia się spod władzy paradygmatu romantycznego. Stanisław Godlewski pisze:

[aktorzy] stają przed widzami $\mathrm{w}$ różnych punktach sceny (widownia otacza scenę z trzech stron) i zaczynają tańczyć. Każdy ma własny, charakterystyczny układ inspirowany różnymi technikami choreograficznymi. Początkowo ruch jest minimalny, subtelny - delikatne drgnienia palców, płytkie skłony, powolne wznoszenie ramion. $Z$ czasem staje się coraz bardziej dynamiczny. Prosta, a bardzo efektowna sekwencja jest dziełem choreografki i tancerki Agnieszki Kryst, która świetnie uruchomiła ciała aktorów - ruch w całym spektaklu jest bardzo precyzyjnie zaplanowany i wypływa organicznie $\mathrm{z}$ charakteru danych scen ${ }^{16}$.

W owej indywidualizacji gestów, skoncentrowania się Kordianki i Kordianów na rytmie własnego oddechu, można upatrywać jedną z pierwszych deklaracji wpisanych w spektakl Jakuba Skrzywanka: niechęć do mówienia wspólnym głosem, w imieniu (jakkolwiek pojętej) zbiorowości.

Mimo że do tego momentu w spektaklu nie pada ani jedno słowo pochodzące z dramatu Słowackiego, rama skonstruowana przez reżysera sprawia wrażenie, iż jednym $z$ tematów przedstawienia jest sam język romantyzmu, skonfrontowanie go ze współczesnym odbiorcą i zdemaskowanie jego fałszywie brzmiących tonów. Pierwsza sekwencja, w której zostaje przywołany tekst Kordiana (rozmowa Kordiana i Laury), stanowi zatem nie tylko próbę zmierzenia się ze stereotypowym postrzeganiem tej sceny (odrzucenie uczuć młodzieńca przez nieczułą wybrankę traktowane jako przyczyna samobójstwa bohatera), lecz także jej kompromitacji. Odegrana w kostiumach, razi sztucznością, podkreślaną przez grę aktorów.

Kordian spotyka się z Laurą, gwiazdy świecą, liście więdną, "ciemny się błękit nieba wyświeca za mgłami". Konrad Cichoń gra Kordiana we fraku (naturalnie, jak Werter, niebieskim), Kornelia Trawkowska ma stylową kremową suknię. Ich ciała niemal się nie poruszają, nie patrzą na siebie, po prostu deklamują wersy Słowackiego ${ }^{17}$

- rekonstruuje Stanisław Godlewski. Konwencjonalność tej sceny wzmocniona zostaje poprzez głośne odczytywanie tekstów didaskaliów. Kordian w końcu "dobywa pistoletu”, „przykłada broń do czoła” i pada, ale wówczas jego rola - wraz z kostiumem - zostaje przejęta przez kolejnych wykonawców. Powtarzana natrętnie kwestia bohatera („to nie z mojej winy!”) pozwala wyraźniej zobaczyć wpisaną $\mathrm{w}$ relację Laury i Kordiana andro-

\footnotetext{
16 S. Godlewski, Siksa mówi: żarty się skończyły, „Gazeta Wyborcza: Poznań", 15.01.2018, http:// poznan.wyborcza.pl/poznan/7,36000,22902872,teatr-polski-w-poznaniu-kordian-w-rezyseriijakuba-skrzywanka.html [dostęp 4.11.2018].

17 Tamże.
} 
centryczną narrację. Laura zostaje sfunkcjonalizowana jako nieczuła kochanka, obarczona winą za niepowodzenie młodzieńca i skazana przez niego na niemające końca wyrzuty sumienia. Dariusz Kosiński stwierdza:

gdy w obliczu samobójczej decyzji Kordiana Laura, używając słów Księdza spowiadającego w akcie III bohatera skazanego na śmierć, odmawia swojej odpowiedzialności za jego nieszczęścia, zrywa wieloletnią projekcję czyniącą Laurę winną tego, że młody panicz wypalił sobie w głowę (pudłując zresztą). Nie ma jej zgody na obsadzenie $w$ roli, $w$ jaką wciskano ją od lat, i to jej decyzja staje się podstawą całej sceny ${ }^{18}$.

Etiuda z Laurą stanowi jedyną reprezentację aktu pierwszego Kordiana. Z aktu drugiego zostaną przywołane sceny z Wiolettą i Papieżem, a także monolog na Mont Blanc, z trzeciego - dyskusja Kordiana z Prezesem, strzępy sceny przed sypialnią carską (Strach i Imaginacja) i rozmowy z Doktorem. Nietrudno zauważyć, że są to te elementy dramatu Słowackiego, które najsilniej podlegają władzy stereotypu. Skrzywanek przywołuje je jedne po drugich, obnażając pułapki powierzchownej lektury Kordiana, nie rezygnując przy tym $z$ prowadzenia $w$ tle równoległej narracji, ekwiwalentyzującej budowę dramatu.

Taki właśnie status ma kolejna etiuda, rozgrywająca się u podnóża klifów w Dover. "Zwłoki” Kordiana zostają tam odnalezione przez ekspedycję badawczą, która wśród huku morskich fal próbuje się zmierzyć z fenomenem śmierci bohatera romantycznego. Scena, w której Kordian, siedząc na „białej kredowej skale nad morzem, czyta Szekspira", pomijana w powierzchownej lekturze, należy do najważniejszych fragmentów dramatu Słowackiego. W szkicu poświęconym nihilistycznemu potencjałowi Kordiana Michał Kuziak pisze:

Jak sądzę, w związku z prowadzonymi w dramacie grami tekstowymi, kluczowa okazuje się scena na Mont Blanc oraz lustrzana wobec niej scena $\mathrm{Na}$ skatach $w$ Dover. Owo przeglądanie się pierwszej z wymienionych scen $\mathrm{w}$ drugiej podważa sens idei odnalezionej przez bohatera: dzięki aluzji literackiej, będącej odwołaniem do Króla Leara i budowania przez Szekspira góry ze słów. Podważenie takie dokonuje się również przez odsłonięcie szatańskiej inspiracji tkwiącej w idei poświęcenia się (epifanii na Mont Blanc towarzyszą "czarne skrzydła” myśli bohatera), a także przez zderzenie realistycznej konwencji dramatu z techniką iluzji. Wspomniana idea okazuje się $\mathrm{w}$ istocie ideą śmierci i unicestwienia („Poświęci się, choć padnie jak dawniej! jak nieraz” [VI, 219] i później: „Ja się w chwili ofiarnej jak kadzidło spalę!”) ${ }^{19}$.

18 D. Kosiński, Doprawdy, nie wiem, co mu jest, s. 69.

19 M. Kuziak, Słowacki - nihilistyczny? Wokót „Kordiana”, s. 189. 
Na poznańskiej scenie szekspirowska i romantyczna legenda klifu zostają skonfrontowane ze współczesną sławą "skały samobójców” - Beachy Head. Odnaleziony u podnóża skał „kolejny obiekt” wymyka się opisom członków ekspedycji, pozostając do końca zagadką, wzbudzającą opór i dystans. Zwraca uwagę także gra z językiem Różewiczowskich Świadków:

- Co tam znów widzisz?

- Nic ciekawego.

- Cicho... Zdaje mi się, że czołga się w naszą stronę.

- Nie, to się nie rusza.

- Może morze to wyrzuciło.

- Podnosi głowę... widzę oczy i usta, on się patrzy na mnie.

- Nie, to się na nic nie patrzy.

- Nic, nic o mnie nie wiesz, nie znasz mnie... [...]

- To jest coś wielkiego.

- Nie, to nie jest nic wielkiego.

- To musiało dokonać wielkich rzeczy.

- Nie, to niczego nie dokonało [...]

- Jeśli cię to interesuje, to chodź tu i zobacz.

- Tak bardzo mnie nie interesuje.

- Nie ma jakiegoś znaczka, obrączki, dowodu, nie zostawił po sobie żadnego listu, wspomnienia, marzenia, nie miał żadnych ideałów, żadnych wzniosłych myśli, które mogłyby poruszyć lub wzruszyć tłumy, ja na jego miejscu pozostawiłbym pustą przestrzeń wypełnioną dźwiękiem.

Twórcy spektaklu cofają się jednak przed ostateczną dyskredytacją samobójczego skoku - w przeciwieństwie do wyraźnie zwerbalizowanego protestu wobec poświęcenia się za naród, co wybrzmi wyraźnie podczas sceny na Mont Blanc. Zanim to jednak nastąpi, Skrzywanek dokonuje konfrontacji Kordiana z kolejnym wcieleniem kobiecości. Scena w „Willi włoskiej” tradycyjnie czytana była jako figura kolejnego rozczarowania bohatera, który orientuje się, że sensu życia nie odnajdzie w ramionach pięknej i sprzedajnej Wioletty. Wiernie odegrana przez Alex Freiheit i Pawła Siwiaka prowadzi jednak twórców przedstawienia do zaskakującej wolty. Kiedy bowiem dialog dobiega końca, Siwiak zwraca się do siedzącego na postumencie Wiesława Zanowicza: „Wiesiu, a jak ty grałeś Kordiana, to o czym to była scena?". Odpowiedź „Kordiana'79” („Scena o doświadczeniach miłosnych. Kordian spotyka pazerną włoską kurwę. Rozżalony fałszywymi uczuciami, rzuca nią jak ścierką o podłogę, świadom, że są wyższe cele nad nieszczęśliwą miłość - jak poświęcenie się za ojczyznę") staje się impulsem do zerwania narracji spektaklu i odśpiewania przez Freiheit przeboju Grażyny Giżowskiej Będę gwiazda („O mnie nie martw się. Dobrą passę mam / Ktoś odkryje mnie. Zobaczysz sam / Będę pierwszą gwiazdą w filmie. Będę grała główne role / 
A ty będziesz wtedy przy mnie jak Riviera po sezonie"). Spojrzenie na postać Wioletty ponad filtrem narzucanym przez perspektywę Kordiana jest kolejnym gestem kompromitującym postać romantycznego bohatera. „Kobiecy głos niezgody na podtrzymywane przez romantyzm mizoginistyczne schematy" ${ }^{20}$ brzmi mocno i odważnie, zmuszając do dostrzeżenia w tekście Słowackiego płaszczyzny, która zazwyczaj nie jest przedmiotem uwagi badaczy literatury romantycznej.

Po zawodzie uczuciowym w biografii Kordiana przychodzi czas na rozczarowanie religijne - scena „w Watykanie” zostaje przez Skrzywanka rozegrana jako konfrontacja skrajnie odmiennych figur papiestwa: pierwszej - utrwalonej w wizerunku schorowanego Jana Pawła II i drugiej - olśniewającego urodą "młodego papieża” z serialu Paola Sorrentino. Skojarzenia twórców spektaklu tylko pozornie wykraczają poza krąg tematów poruszanych przez Słowackiego. Jeśli bowiem sens sceny w Watykanie można sprowadzić do rozczarowania bohatera religią, „reprezentowaną w dramacie przez papiestwo, odmawiające Polakom prawa do walki o wolność" 21, to słowa "młodego papieża” - ,jest tylko jedna droga do szczęścia i tą drogą jest wolność" - nabierają w narracji twórców przedstawienia charakteru aksjomatu.

Kulminacyjny - w tradycyjnej lekturze - punkt Kordiana następuje jednak dopiero w scenie monologu na Mont Blanc. Ironiczna i pełna dystansu scena zostaje rozegrana po mistrzowsku - grupa Kordianek i Kordianów, poruszająca się w zwolnionym tempie w śnieżnej zamieci, wypowiada na głosy tekst monologu Kordiana, ujawniając nie tylko jego wszystkie sprzeczności i niekonsekwencje („Mogę - więc pójdę - ludy zawołam! Obudzę!”; „Może lepiej się rzucić w lodowe szczeliny?"), lecz także obnażając fałsz przeistoczenia, którego bohater rzekomo miał doznać na Mont Blanc. Ubrana w futro białego niedźwiedzia Sonia Roszczuk kompromituje winkelriedyczne mrzonki Kordiana, by po chwili, posługując się tekstami Prezesa ze sceny „w podziemiach katedry", zdyskredytować zarówno chęć samobójczego złożenia się na ołtarzu ojczyzny, jak i zamiar morderstwa cara, który wydał się Kordianowi odpowiedzią na kryzys egzystencji ${ }^{22}$. Mimo dekonstrukcji ofiarniczego mitu, rola bohatera romantycznego zostaje podjęta przez kolejnego z aktorów -

\footnotetext{
20 D. Kosiński, Doprawdy, nie wiem, co mu jest, s. 69.

21 M. Kuziak, Słowacki - nihilistyczny? Wokót „Kordiana”, s. 188.

22 Por. W. Szydłowska-Brykczyńska, Egzystencjalistyczne królestwo albo romantyzm na wygnaniu, s. 60-70. Por. także J. Mikołajczyk, Czy Kordian byt terrorystą? Noc romantyczna jako (przed)świt romantyzmu, w: Noce romantyków. Literatura - kultura - obyczaj, red. M. Ursel, D. Skiba, A. Rej, Kraków 2015, s. 11-21.
} 
tym razem o swoim mierzeniu się z nią opowie, wpisując własną biografię w historię tych zmagań, Wiesław Zanowicz.

Wybrzmiewające ze sceny prywatne głosy aktorów wprowadzają do spektaklu Jakuba Skrzywanka nowe akcenty. To miejsca, w których nawias ironii zostaje zawieszony, a kwestia stosunku do "gorączki romantycznej" nabiera charakteru programowej deklaracji. Inkrustowana głosami Strachu i Imaginacji historia Zanowicza - aktora, który ma za sobą doświadczenie współpracy z służbą bezpieczeństwa i emigracji - zostaje wpisana w kontekst historii Polski okresu transformacji i wprowadza do poznańskiego spektaklu „ton rozliczenia z młodzieńczymi zapałami, zniszczonymi później przez podstępną niegodziwość świata wykorzystującego nasze błędy i słabości" ${ }^{23}$. Prawdziwym punctum spektaklu Skrzywanka staje się jednak dopiero performance Aleks Freiheit - wokalistki wcielającej się w postać superbohaterki Siksy, która "sztyletem słowa zabija ludzi głupich albo wrogów”. Wyskandowana do mikrofonu opowieść o doświadczeniu gwałtu i o mierzeniu się dzień po dniu z własnym carem staje się manifestem (kobiecej) siły wobec zaprogramowanej w Kordianie (męskiej) słabości. Jest także wyzwaniem rzuconym romantycznym poetom, którzy w kobietach chcieli widzieć wyłącznie Laury albo Wioletty.

Sama jest Kordianką; zabawy w polskość jej nie interesują, w to miejsce wprowadza tematy kobiece. $\mathrm{W}$ bliskim kontakcie $\mathrm{z}$ publicznością do ucha widzom wykrzykuje mocne oskarżenia o wykorzystywanie seksualne kobiet

- pisał Piotr Morawski, który spektakl Skrzywanka nazwał „najmocniejszą teatralną wypowiedzią w sprawie \#metoo" 24 . Siksa krzyczy także ze sceny, że obowiązkiem patriotycznym jest dbanie o wolność każdego człowieka. W jej ustach kierowane do widzów słowa Kordiana „Wy jesteście krainy sumnienie, Zburzcie się i z dusz waszych odrzućcie grzech cara" brzmią silnie i bezkompromisowo, jak $\mathrm{w}$ niezafałszowanym przez lata recepcji dramacie Słowackiego.

W finale spektaklu dochodzi do uroczystego pochówku Kordiana. Nad jego grobem stojąca na czele żałobników "kobieta w żałobie” formułuje rodzaj manifestu skierowanego przeciwko romantycznej apologii wielkości. Niechęć wobec „wielkich bohaterów, historii, słów, gestów, rewolucji i systemów” staje się wspólnym głosem twórców poznańskiego Kordiana.

23 D. Kosiński, Doprawdy, nie wiem, co mu jest, s. 69.

24 P. Morawski, Inna polityka jest możliwa, „Dialog” 2018, nr 10, s. 153. 
My, którzy urodziliśmy się w czasie transformacji '89, wychowani w wolnej Polsce obarczonej mitami wykluczających się narracji historycznych i ciągłej walki między martyrologią a chęcią jej negacji, próbujemy wciąż, albo na powrót, odpowiedzieć sobie na pytania dawno już postawione i sprawdzamy, czy nasz głos ma dziś jakąkolwiek sprawczość, czy może wywołać rewolucję, zwłaszcza w instytucji, jaką jest dzisiejszy Teatr w Polsce ${ }^{25}$.

- mówi także kolektywna deklaracja, zamieszczona na stronie internetowej Teatru Polskiego w Poznaniu. Podkreślana wcześniej niechęć do wypowiadania się $\mathrm{w}$ imieniu zbiorowości $\mathrm{w}$ tym jednym przypadku została zastąpiona wspólnym głosem protestu wobec paradygmatu romantycznego.

Z pewnością strategia, którą przyjął wobec Kordiana Jakub Skrzywanek, nie jest klasyczną próbą lektury dramatu romantycznego. Poprzez zmierzenie się z powidokami dokonywanych przez lata lektur utworu, autorzy spektaklu osiągnęli jednak znacznie więcej niż którykolwiek z inscenizatorów dramatu Słowackiego w ostatnich latach. Kompromitując bowiem kolejne romantyczne stereotypy i poddając próbie ich siłę sprawczą, włączyli się do debaty publicznej, która toczy się na polskiej scenie od kwietnia 2010 roku. W sytuacji, w której dziedzictwo polskiego romantyzmu zostaje zawłaszczone przez nacjonalizujące i skrajnie konserwatywne narracje, wątpliwości formułowane przez twórców poznańskiego Kordiana brzmią nadspodziewanie aktualnie.

Pobieżna analiza struktury Kordiana Jakuba Skrzywanka może wzbudzić w gronie filologów podejrzenie, że jego związki z dramatem Juliusza Słowackiego zeszły na dalszy plan. Jeśli jednak przyjrzeć się poznańskiemu spektaklowi uważniej, okazuje się, że są w nim obecne najważniejsze tematy Kordiana: kwestia wolności, waga indywidualnych decyzji, bunt przeciwko Mickiewiczowskiemu modelowi romantyzmu.

Tym zaś, co zasługuje w spektaklu Jakuba Skrzywanka na najwyższe uznanie, jest konstrukcja spektaklu, stanowiąca sceniczną manifestację gatunku dramatu romantycznego. W swojej hybrydyczności, mieszaniu tonów wypowiedzi, poetyce fragmentu, posługiwaniu się formą otwartą i grze z kategorią ironii, poznański Kordian sięga wprost do korzeni romantycznego teatru. Sądzę także, że spektakl mógłby się spodobać Juliuszowi Słowackiemu - jedynemu w polskim romantyzmie twórcy pełnokrwistych postaci kobiecych i jednocześnie ironiście, ceniącemu sobie metodę "kąsania sercem”.

25 Premiera numer 4189, http://teatr-polski.pl/spektakle/kordian/ [dostęp 4.11.2018]. 


\section{Bibliografia}

Bizan Marian, Hertz Paweł (1972), Glosy do „Kordiana”, Warszawa: Państwowy Instytut Wydawniczy.

Chacko Magdalena (2006), Dramat i teatr Juliusza Słowackiego. Rekonesans, Wrocław: Wydawnictwo Uniwersytetu Wrocławskiego.

Fieguth Rolf (2001), Granice ironii w „Kordianie” Juliusza Słowackiego, w: Ciało, płeć, literatura. Prace ofiarowane prof. Germanowi Ritzowi, w pięćdziesiąta rocznicę urodzin, red. M. Hornung, M. Jędrzejczak, Warszawa: Wiedza Powszechna, s. 9-24.

Godlewski Stanisław (2018), Siksa mówi: żarty się skończyły, "Gazeta Wyborcza Poznań", 15 stycznia 2018, http://poznan.wyborcza.pl/poznan/7,36000,22902872, teatr-polski-w-poznaniu-kordian-w-rezyserii-jakuba-skrzywanka.html.

Kaczyńska Leokadia (2006), Winkelried ożyt. Teatralne odczytywanie „Kordiana” (1945-2000), Gdańsk: Słowo/Obraz Terytoria.

Kosiński Dariusz (2018), Doprawdy, nie wiem, co mu jest, „Tygodnik Powszechny”, nr 7, s. $68-70$.

Kurska Anna (2006), Fragment i całość w dramaturgii Juliusza Słowackiego, w: Słowacki teatralny, red. K. Kurek, Poznań: Wydawnictwo Naukowe UAM, s. 85-126.

Kuziak Michał (2009), Słowacki - nihilistyczny? Wokót „Kordiana”, w: Nihilizm i historia. Studia z literatury XIX i XX wieku, red. M. Sokołowski, J. Ławski, Białystok: Trans Humana, Warszawa: IBL PAN, s. 171-199.

Maciejewski Janusz (1961), Kordian. Dramatyczna trylogia, Poznań: Wydawnictwo Poznańskie.

Masłowski Michał (1978), Dzieje bohatera. Teatralne wizje „Dziadów”, "Kordiana” $i$ "Nie-Boskiej Komedii" do II wojny światowej, Wrocław: Zakład Narodowy im. Ossolińskich.

Mikołajczyk Jacek (2015), Czy Kordian był terrorysta. Noc romantyczna jako (przed)świt romantyzmu, w: Noce romantyków. Literatura - kultura - obyczaj, red. M. Ursel, D. Skiba, A. Rej, Kraków: Universitas, s. 11-22.

Morawski Piotr (2018), Inna polityka jest możliwa, „Dialog”, nr 10, s. 145-155.

Piwińska Marta (2005), Złe wychowanie, Gdańsk: Słowo/Obraz Terytoria.

Siwiec Magdalena (2009), Słowacki i nowoczesność, w: Romantyzm i nowoczesność, red. M. Kuziak, Kraków: Universitas, s. 109-164.

Szydłowska-Brykczyńska Waleria (1991), Egzystencjalistyczne królestwo albo romantyzm na wygnaniu, Chotomów: Verba.

Szostak Violetta (2018), Jakub Skrzywanek: Chce pochować Kordiana. Teatr Polski wystawia dzieło Słowackiego. Punkowa Siksa w roli Kordianki, "Gazeta Wyborcza Poznan”,, 12 stycznia 2018, http://poznan.wyborcza.pl/poznan/7,105531,22883342,jakubskrzywanek-chce-pochowac-kordiana-teatr-polski-wystawia.html?disableRedire cts $=$ true. 


\section{Over the Coffin of a Romantic Hero}

\section{Summary}

The article is an analysis and interpretation of Juliusz Słowacki's Kordian directed by Jakub Skrzywanek at the Polish Theatre in Poznan in January 2018. Although it is a discussion with romantic stereotypes and myths, rather than another classical staging of the play, Skrzywanek's staging is one of the most interesting voices in the Kordian case in years. This essay is an attempt to reconstruct the performance on the basis of its reviews and statements of the staging's creators.

Keywords: theatre, performance, review, romanticism, stereotype 